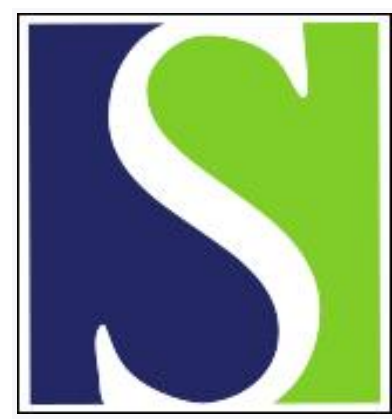

Scand J Work Environ Health 1986;12(4):289-292

https://doi.org/10.5271/sjweh.2150

Issue date: Aug 1986

Epidemiologic survey of vibration syndrome among riveters, chippers and grinders in the railroad system of the People's Republic of China.

by Yu ZS, Chao H, Qiao L, Qian DS, Ye YH

The following article refers to this text: 2010;36(6):509-513

This article in PubMed: www.ncbi.nlm.nih.gov/pubmed/3490686

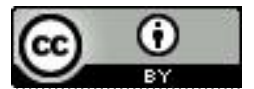




\title{
Epidemiologic survey of vibration syndrome among riveters, chippers and grinders in the railroad system of the People's Republic of China
}

\author{
by Yu Zeng-Shun, Chao Hu, Qiao Ling, Qian De-Sheng, Ye Yu-Hua ${ }^{1}$
}

\begin{abstract}
YU Z-S, CHAO H, QIAO L, QIAN D-S, YE Y-H. Epidemiologic survey of vibration syndrome among riveters, chippers and grinders in the railroad system of the People's Republic of China. Scand $J$ Work Environ Health 12 (1986) 289-292. Vibration syndrome caused by hand-held vibrating tools in 14 locomotive and rolling stock plants in four regions of the People's Republic of China (south, north, middlewest, and northeast) and the influence of climatic factors on its prevalence rate were studied. For 1028 male workers ( 705 riveters, 284 chippers, and 39 grinders), the prevalence rate of the syndrome was $13.4 \%$ and for a reference group of 256 workers it was $1.6 \%$. The prevalence rate of white finger in the four regions differed and was higher in northeast and north China than in south and middlewest China. This finding suggests that cold climate and humidity may be causative factors of the vibration syndrome.
\end{abstract}

Key terms: cold climate, region, vibration-induced white finger.

Hand-held vibrating tools, which endanger the health of workers, are still commonly used in some productive processes. After Zhang \& Gu (7) first reported grinders with the vibration syndrome in 1959 , a series of reports has been published. The syndrome has attracted the attention of physicians. Since vibrating tools are widely used in locomotive and rolling stock repair plants, it is essential to study the causative factors of the syndrome and its effect on the health of workers.

\section{Subjects and methods}

One thousand and twenty-eight male workers (705 riveters, 284 chippers, and 39 grinders) were studied. Their ages ranged from 17 to 60 years, the mean being 32 years. Two hundred and fifty-six male workers, including turners, fitters and electricians, served as referents. Their age range was $17-59$ (mean 33) years. The age and duration of work of the two groups were similar.

The items of study included climate in four regions (south, north, middlewest, and northeast China), work conditions, vibrating tools, vibration levels, time of exposure to vibration each shift, occupational history, subjective symptoms, and hand examinations including the determination of pain sensation (6) and fingertip sensation (2) (depth sense esthesiometry and two-point discrimination).

The diagnosis of vibration-induced white finger (VWF) was based upon subject's complaints that were confirmed by co-workers and the results of the physi-

\footnotetext{
1 Institute of Industrial Hygiene, Ministry of Railways, YangFang-Dian 103, Beijing, People's Republic of China.

Reprint requests to: $\mathrm{Mr} \mathrm{Yu} \mathrm{ZS}$, Institute of Industrial Hygiene, Ministry of Railways, Yang-Fang-Dian 103, Beijing, People's Republic of China.
}

cal examination. The data from the study were analyzed for the following three groups: exposed subjects with VWF, exposed subjects without VWF, and referents.

\section{Results}

\section{General data}

The 14 plants for repairing locomotives and freight cars consisted of large workshops with imperfect facilities for temperature preservation. Vehicles were moved in and out frequently, and in winter the temperature indoors and outdoors was not much different. The climate in the four regions is shown in table 1.

The riveters were exposed to vibration on an average for $0.76 \mathrm{~h} / \mathrm{d}$, chippers for $1.02 \mathrm{~h} / \mathrm{d}$, and grinders for $2.6 \mathrm{~h} / \mathrm{d}, 6 \mathrm{~d}$ a week. Field measurement and frequency analysis showed that vibration levels of the tools all exceeded the limits defined in ISO/DIS 5349 (4).

\section{Prevalence rate}

Of the 1028 workers, $138(13.4 \%)$ had VWF. In the reference group four $(1.6 \%)$ had constitutional white finger (CWF). The difference in prevalence between the two groups was significant $(p<0.001)$. The prevalence of VWF in the different regions (table 2) was $19.4 \%$ in the northeast, $19.2 \%$ in the north, $9.1 \%$ in the middlewest, and $7.3 \%$ in the south. Statistical analysis showed that, apart from the northeast versus north and middlewest versus south, there was a significant difference in the prevalence between the regions $(p<0.01$ or $p<0.001)$. The prevalence of VWF also tended to increase as the duration of work increased in the exposed group (table 3), as was evi- 
Table 1. Climate in the four regions of China.

\begin{tabular}{lcccc}
\hline Region & $\begin{array}{c}\text { Number } \\
\text { of plants }\end{array}$ & $\begin{array}{c}\text { Mean annual } \\
\text { temperature }\left({ }^{\circ} \mathrm{C}\right)\end{array}$ & $\begin{array}{c}\text { Mean annual } \\
\text { humidity }(\%)\end{array}$ & Climate \\
\hline South China & 5 & $15.0-20.2$ & $75-78$ & Subtropical, moist, monsoon \\
North China & 3 & $9.5-11.5$ & $50-60.5$ & Temperate, semimoist, continental \\
Middlewest China & 3 & $9-13$ & $38-49$ & Temperate, arid, continental \\
Northeast China & 3 & $4.5-7.8$ & $70-75$ & Frigid, temperate, moist \\
\hline
\end{tabular}

Table 2. Prevalence rate of vibration-induced white finger (VWF) among three types of workers.

\begin{tabular}{|c|c|c|c|c|c|c|c|c|c|c|}
\hline \multirow[b]{2}{*}{ Region } & \multirow{2}{*}{$\begin{array}{c}\text { Total } \\
\text { number } \\
\text { of } \\
\text { subjects }\end{array}$} & \multicolumn{3}{|c|}{ Riveters } & \multicolumn{3}{|c|}{ Chippers } & \multicolumn{3}{|c|}{ Grinders } \\
\hline & & $\begin{array}{c}\text { Number } \\
\text { of } \\
\text { subjects }\end{array}$ & $\begin{array}{l}\text { Number } \\
\text { with } \\
\text { VWF }\end{array}$ & $\begin{array}{l}\text { Percentage } \\
\text { with } \\
\text { VWF }\end{array}$ & $\begin{array}{c}\text { Number } \\
\text { of } \\
\text { subjects }\end{array}$ & $\begin{array}{l}\text { Number } \\
\text { with } \\
\text { VWF }\end{array}$ & $\begin{array}{l}\text { Percentage } \\
\text { with } \\
\text { VWF }\end{array}$ & $\begin{array}{l}\text { Number } \\
\text { of } \\
\text { subjects }\end{array}$ & $\begin{array}{l}\text { Number } \\
\text { with } \\
\text { VWF }\end{array}$ & $\begin{array}{c}\text { Percentage } \\
\text { with } \\
\text { VWF }\end{array}$ \\
\hline \multirow{3}{*}{$\begin{array}{l}\text { South China } \\
\text { North China } \\
\text { Middlewest } \\
\text { China } \\
\text { Northeast } \\
\text { China } \\
\end{array}$} & $\begin{array}{l}327 \\
234\end{array}$ & $\begin{array}{l}236 \\
162\end{array}$ & $\begin{array}{l}16 \\
36\end{array}$ & $\begin{array}{r}6.8 \\
22.2\end{array}$ & $\begin{array}{l}80 \\
68\end{array}$ & $\begin{array}{l}5 \\
6\end{array}$ & $\begin{array}{l}6.3 \\
9.0\end{array}$ & $\begin{array}{r}11 \\
4\end{array}$ & $\begin{array}{l}3 \\
3\end{array}$ & $\begin{array}{l}27.3 \\
75.0\end{array}$ \\
\hline & 209 & 124 & 14 & 11.3 & 63 & 4 & 6.3 & 22 & 1 & 4.5 \\
\hline & 258 & 183 & 37 & 20.2 & 73 & 13 & 17.8 & 2 & - & 0.0 \\
\hline Total & 1028 & 705 & 103 & 14.6 & 284 & 28 & 9.9 & 39 & 7 & 18.0 \\
\hline
\end{tabular}

Table 3. Prevalence rate of vibration-induced white finger (VWF) according to length of exposure.

\begin{tabular}{|c|c|c|c|c|c|c|c|c|c|c|c|c|}
\hline \multirow{3}{*}{ Region } & \multicolumn{12}{|c|}{ Length of exposure (years) } \\
\hline & \multicolumn{2}{|c|}{$1-5$} & \multicolumn{2}{|c|}{$6-10$} & \multicolumn{2}{|c|}{$11-15$} & \multicolumn{2}{|c|}{$16-20$} & \multicolumn{2}{|c|}{$21-25$} & \multicolumn{2}{|c|}{$\geq 26$} \\
\hline & $\begin{array}{l}\text { Number } \\
\text { of } \\
\text { subjects }\end{array}$ & $\begin{array}{l}\text { Percent- } \\
\text { age with } \\
\text { VWF }\end{array}$ & $\begin{array}{l}\text { Number } \\
\text { of } \\
\text { subjects }\end{array}$ & $\begin{array}{l}\text { Percent- } \\
\text { age with } \\
\text { VWF }\end{array}$ & $\begin{array}{l}\text { Number } \\
\text { of } \\
\text { subjects }\end{array}$ & $\begin{array}{l}\text { Percent- } \\
\text { age with } \\
\text { VWF }\end{array}$ & $\begin{array}{c}\text { Number } \\
\text { of } \\
\text { subjects }\end{array}$ & $\begin{array}{l}\text { Percent- } \\
\text { age with } \\
\text { VWF }\end{array}$ & $\begin{array}{l}\text { Number } \\
\text { of } \\
\text { subjects }\end{array}$ & $\begin{array}{l}\text { Percent- } \\
\text { age with } \\
\text { VWF }\end{array}$ & $\begin{array}{l}\text { Number } \\
\text { of } \\
\text { subjects }\end{array}$ & $\begin{array}{l}\text { Percent- } \\
\text { age with } \\
V W F\end{array}$ \\
\hline $\begin{array}{l}\text { South China } \\
\text { North China } \\
\text { Middlewest }\end{array}$ & $\begin{array}{r}119 \\
93\end{array}$ & $\begin{array}{l}1.7 \\
5.4\end{array}$ & $\begin{array}{l}82 \\
57\end{array}$ & $\begin{array}{r}6.1 \\
29.8\end{array}$ & $\begin{array}{l}70 \\
34\end{array}$ & $\begin{array}{r}5.7 \\
29.4\end{array}$ & $\begin{array}{l}22 \\
11\end{array}$ & $\begin{array}{l}13.6 \\
27.3\end{array}$ & $\begin{array}{l}24 \\
21\end{array}$ & $\begin{array}{l}25.0 \\
19.0\end{array}$ & $\begin{array}{l}10 \\
18\end{array}$ & $\begin{array}{l}40.0 \\
33.3\end{array}$ \\
\hline $\begin{array}{l}\text { China } \\
\text { Northeast }\end{array}$ & 81 & 3.7 & 43 & 11.6 & 44 & 9.1 & 21 & 14.3 & 17 & 17.6 & 3 & 33.3 \\
\hline China & 114 & 5.3 & 48 & 10.4 & 38 & 23.7 & 10 & 40.0 & 31 & 58.1 & 17 & 47.1 \\
\hline Total & 407 & 3.9 & 230 & 13.9 & 186 & 14.5 & 64 & 20.3 & 93 & 33.3 & 48 & 39.6 \\
\hline
\end{tabular}

Table 4. Percentage of exposed subjects with general subjective symptoms.

\begin{tabular}{|c|c|c|c|c|c|c|c|}
\hline \multirow{2}{*}{ Region } & \multirow{2}{*}{$\begin{array}{l}\text { Number of } \\
\text { subjects }\end{array}$} & \multicolumn{6}{|c|}{ General subjective symptom } \\
\hline & & Headache & Dizziness & $\begin{array}{l}\text { Failing } \\
\text { of memory }\end{array}$ & Insomnia & $\begin{array}{l}\text { Palpi- } \\
\text { tation }\end{array}$ & $\begin{array}{l}\text { Irrita. } \\
\text { bility }\end{array}$ \\
\hline $\begin{array}{l}\text { South China } \\
\text { North China } \\
\text { Middlewest }\end{array}$ & $\begin{array}{l}327 \\
234\end{array}$ & $\begin{array}{l}28.4 \\
21.8\end{array}$ & $\begin{array}{l}68.2 \\
58.5\end{array}$ & $\begin{array}{l}61.5 \\
67.9\end{array}$ & $\begin{array}{l}48.6 \\
52.6\end{array}$ & $\begin{array}{l}39.1 \\
52.6\end{array}$ & $\begin{array}{l}52.3 \\
57.3\end{array}$ \\
\hline $\begin{array}{l}\text { China } \\
\text { Northeast }\end{array}$ & 209 & 27.3 & 51.2 & 59.3 & 43.1 & 40.1 & 13.4 \\
\hline China & 258 & 24.4 & 61.6 & 74.0 & 53.5 & 60.5 & 53.9 \\
\hline Total & 1028 & 25.7 & 60.9 & 65.7 & 49.6 & 47.9 & 45.9 \\
\hline Reference group & 256 & 18.4 & 28.9 & 36.3 & 21.9 & 19.9 & 9.0 \\
\hline
\end{tabular}

dent from the regression analysis $(t=8.87, \mathrm{~N}=4$, $\mathrm{p}<0.005)$.

The average latency period of the $138 \mathrm{VWF}$ cases was 9.2 (SD 6.9) years.
Subjective symptoms

The subjective symptoms of the exposed subjects are listed in tables 4 and 5 . Comparison of the exposed groups with a reference group disclosed that there was 
Table 5. Percentage of exposed subjects with local subjective symptoms.

\begin{tabular}{|c|c|c|c|c|c|c|c|c|}
\hline \multirow{2}{*}{ Region } & \multirow{2}{*}{$\begin{array}{l}\text { Number of } \\
\text { subjects }\end{array}$} & \multicolumn{7}{|c|}{ Local subjective symptom } \\
\hline & & Numbness & Pain & Spasm & Stiffness & Sweating & Cold & Tingling \\
\hline $\begin{array}{l}\text { South China } \\
\text { North China }\end{array}$ & $\begin{array}{l}327 \\
234\end{array}$ & $\begin{array}{l}47.4 \\
57.7\end{array}$ & $\begin{array}{l}16.2 \\
26.5\end{array}$ & $\begin{array}{l}14.4 \\
23.5\end{array}$ & $\begin{array}{l}20.8 \\
22.6\end{array}$ & $\begin{array}{l}48.6 \\
50.0\end{array}$ & $\begin{array}{l}37.3 \\
33.3\end{array}$ & $\begin{array}{l}27.8 \\
26.9\end{array}$ \\
\hline China & 209 & 40.2 & 13.4 & 17.2 & 17.2 & 50.2 & 19.6 & 22.0 \\
\hline China & 258 & 54.3 & 22.1 & 18.6 & 24.4 & 60.9 & 42.2 & 47.3 \\
\hline Total & 1028 & 50.0 & 19.5 & 18.1 & 21.4 & 52.3 & 34.0 & 31.3 \\
\hline $\begin{array}{l}\text { Reference } \\
\text { group }\end{array}$ & 256 & 13.3 & 0.8 & 1.2 & 0.8 & 20.7 & 6.3 & 5.9 \\
\hline
\end{tabular}

a significant difference $(\mathrm{p}<0.05)$ for the symptom headache and highly significant differences $(p<0.001)$ for the other items. The occurrence rate of the symptoms in northeast China was higher than in the other regions.

\section{Physical examination}

The results of a physical examination showed significant differences $(p<0.01)$ between the exposed group (with VWF, without VWF) and the reference group in each region, as well as overall (table 6).

\section{Pain test}

The mean pain threshold in both hands was 0.34 (SD $0.12) \mathrm{mm}$ in the reference group, $0.40(\mathrm{SD} 0.16) \mathrm{mm}$ in exposed group without VWF, and 0.5 (SD 0.25$) \mathrm{mm}$ in the exposed group with VWF. The t-test showed that there were significant differences between the groups, but not between the four regions, for this parameter.

\section{Fingertip sensation}

Table 7 shows the mean depth sense and two-point discrimination thresholds of both hands. There were significant differences between the groups, but not between the regions.
Table 6. Percentage of subjects with findings in the physical examination. ( $V W F=$ vibration-induced white finger)

\begin{tabular}{lrrr} 
& \multicolumn{3}{c}{ Finding } \\
\cline { 2 - 4 } Region & $\begin{array}{c}\text { Amyo- } \\
\text { trophia } \\
\text { tenderness }\end{array}$ & $\begin{array}{c}\text { De- } \\
\text { formity }\end{array}$ & $\begin{array}{r}\text { Tin- } \\
\text { gling }\end{array}$ \\
\hline South China & & & \\
Exposed subjects & & & \\
With VWF $(N=24)$ & 25.0 & 41.7 & 37.5 \\
Without VWF $(N=303)$ & 3.3 & 12.5 & 11.2 \\
Referents $(N=79)$ & 0.0 & 1.3 & 1.3 \\
North China & & & \\
Exposed subjects & & & \\
With VWF $(N=45)$ & 20.0 & 24.4 & 31.1 \\
Without VWF $(N=189)$ & 12.2 & 15.9 & 27.0 \\
Referents $(N=71)$ & 0.0 & 0.0 & 4.2 \\
Middlewest China & & & \\
Exposed subjects & & & \\
With VWF $(N=19)$ & 31.6 & 36.8 & 26.3 \\
Without VWF $(N=190)$ & 2.6 & 9.5 & 12.1 \\
Referents $(N=43)$ & 0.0 & 0.0 & 2.3 \\
Northeast $C h i n a$ & & & \\
Exposed subjects & & & \\
With VWF $(N=50)$ & 12.0 & 38.0 & 46.0 \\
Without $V W F(N=208)$ & 8.2 & 22.1 & 31.7 \\
Referents $(N=63)$ & 0.0 & 0.0 & 0.0 \\
\hline
\end{tabular}

Table 7. Thresholds of depth sense and two-point discrimination.

\begin{tabular}{|c|c|c|c|c|c|c|c|c|c|c|}
\hline \multirow{2}{*}{$\begin{array}{l}\text { Fingertip } \\
\text { sensation }\end{array}$} & \multicolumn{2}{|c|}{ South China } & \multicolumn{2}{|c|}{ North China } & \multicolumn{2}{|c|}{$\begin{array}{l}\text { Middlewest } \\
\text { China }\end{array}$} & \multicolumn{2}{|c|}{$\begin{array}{c}\text { Northeast } \\
\text { China }\end{array}$} & \multicolumn{2}{|c|}{ Total } \\
\hline & Mean & SD & Mean & SD & Mean & SD & Mean & SD & Mean & SD \\
\hline \multicolumn{11}{|l|}{ Depth sense } \\
\hline \multicolumn{11}{|l|}{ Exposed subjects } \\
\hline $\begin{array}{l}\text { With VWF } \\
\text { Without VWF } \\
\text { Referents }\end{array}$ & $\begin{array}{l}0.44 \\
0.30 \\
0.21\end{array}$ & $\begin{array}{l}0.30 \\
0.14 \\
0.11\end{array}$ & $\begin{array}{l}0.40 \\
0.35 \\
0.19\end{array}$ & $\begin{array}{l}0.28 \\
0.23 \\
0.09\end{array}$ & $\begin{array}{l}0.66 \\
0.31 \\
0.24\end{array}$ & $\begin{array}{l}0.43 \\
0.23 \\
0.18\end{array}$ & $\begin{array}{l}0.53 \\
0.35 \\
0.19\end{array}$ & $\begin{array}{l}0.31 \\
0.19 \\
0.13\end{array}$ & $\begin{array}{l}0.51 \\
0.33 \\
0.21\end{array}$ & $\begin{array}{l}0.33 \\
0.19 \\
0.13\end{array}$ \\
\hline \multicolumn{11}{|c|}{ Two-point discrimination (mm) } \\
\hline $\begin{array}{l}\text { Exposed subject } \\
\text { With VWF } \\
\text { Without VWF } \\
\text { Referents }\end{array}$ & $\begin{array}{l}2.37 \\
1.75 \\
1.39\end{array}$ & $\begin{array}{l}0.96 \\
0.63 \\
0.61\end{array}$ & $\begin{array}{l}2.22 \\
1.97 \\
1.01\end{array}$ & $\begin{array}{l}1.04 \\
0.66 \\
0.41\end{array}$ & $\begin{array}{l}2.86 \\
1.78 \\
1.45\end{array}$ & $\begin{array}{l}1.37 \\
0.85 \\
0.7\end{array}$ & $\begin{array}{l}2.48 \\
1.83 \\
1.16\end{array}$ & $\begin{array}{l}1.23 \\
0.72 \\
0.55\end{array}$ & $\begin{array}{l}2.48 \\
1.83 \\
1.25\end{array}$ & $\begin{array}{l}1.05 \\
0.72 \\
0.57\end{array}$ \\
\hline
\end{tabular}




\section{Discussion}

The results of our study showed that the prevalence rate of VWF in three types of workers and its overall mean prevalence rate were lower than those reported previously $(1,3,5)$. Of the four regions, the prevalence rates were lower in south and middlewest China. However, our study confirmed that there are sufferers of the vibration syndrome even in the subtropical regions of China. Although the temperature is generally high there, it is damp and cold in winter, and there is no heating at all. Thus, heat loss from the human body is great, and workers may contract VWF after exposure to vibration.

Low temperature is considered to be the main cause of the vibration syndrome (1). This assumption is confirmed by our study in that the prevalence of VWF in the north of China was higher than in the south.

North and middlewest China are at similar latitudes. The latter has a semiarid continental climate, and it is dry with little rainfall. The fact that the prevalence of VWF in this region was lower than that in north China is probably attributable to the relatively minor heat loss from the human body. Whether the incidence of the vibration syndrome is related to humidity awaits further study.

The prevalence of VWF is closely related to the duration of vibration exposure, and it increases as the years of work increase (linear regression equation $\hat{\mathrm{Y}}=$ $1.3857 \mathrm{X}=3.34987$ ).

Vibration disease, a generalized disorder, is induced by hand-arm vibration. Although none of the subjective symptoms are specific, individual diagnosis, epidemiologic study, and statistical analysis has shown that there are significant differences in subjective symptoms (generalized and local) between exposed and re- ference groups. Therefore, some symptoms are specific with respect to the population, such as numbness, pain stiffness, and sweating of the hand. This phenomenon may be significant for the early diagnosis, prevention, and epidemiologic study of the vibration syndrome.

Vibration injury to the peripheral nerves is mainly manifested by the failing of sensory function. After long-term exposure to vibration, pain sensation and tactility may be weakened or may completely disappear. Hence it is advisable that quantitative measurements of pain sense, depth sense, and two-point discrimination be used to determine the degree of damage to the peripheral nerves.

\section{References}

1. Bovenzi M, Petronio L, Di Mario F. Epidemiological survey of shipyard workers exposed to hand-arm vibration. Int Arch Occup Environ Health 46 (1980) 251-266.

2. Carlson WS, Samueloff S, 'Taylor W, Wasserman DE. Instrumentation for measurement of sensory loss in the fingertips. J Occup Med 21 (1979) 260-264.

3. Färkkilä M, Starck J, Hyvärinen J, Kurppa K. Vasospastic symptoms caused by asymmetrical vibration exposure of the upper extremities to a pneumatic hammer. Scand J Work Environ Health 4 (1978) 330-335.

4. International Organization for Standardization. Guidelines for the measurement and the assessment of human exposure to hand-transmitted vibıation. Geneva 1979. (ISO/DIS 5349).

5. Ma LS, Fu Z-H. Epidemiological survey on local vibration for works used pneumatic tools. Chinese Health J 6 (1964) 329-331.

6. Radzzukevich TM. Thresholds of pain sensitivity in workers of "vibration hazardous" occupations and in practically healthy persons of different age. Gig $\operatorname{Tr} 4$ (1974) $10-12$.

7. Zhang ZH, Gu R-J. Raynaud's phenomenon (with analysis of case). People's Health Care 9 (1959) 817-821. 